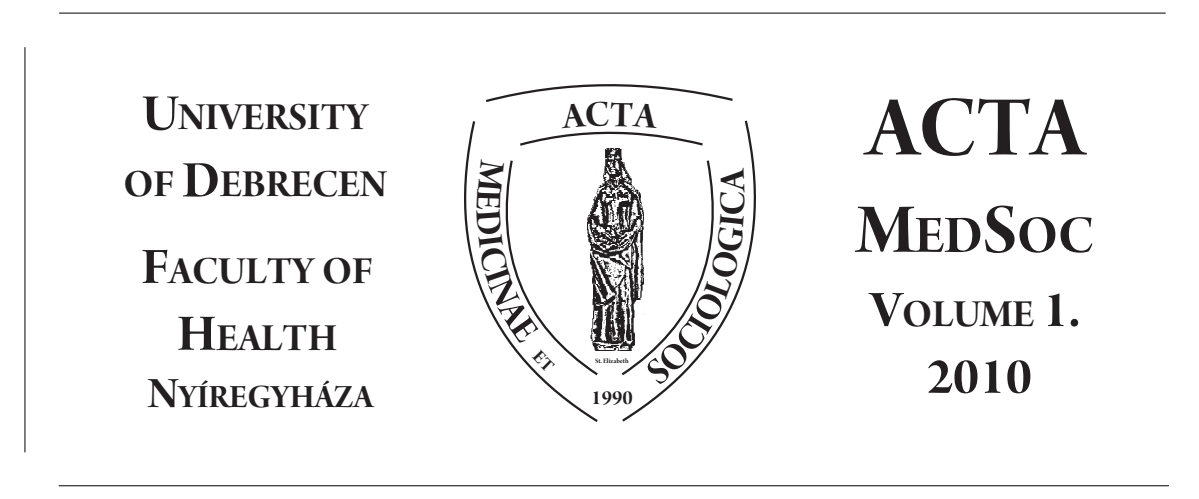

\title{
Irányított verseny - Irányított betegellátás
}

\section{Jóna György ${ }^{1}$ - Kriszbacher Ildikó ${ }^{2}$ - Lukácskó Zsolt ${ }^{1}$}

1 Debreceni Egyetem, Egészségügyi Kar, Alkalmazott Társadalomtudományi Tanszék

2 Pécsi Tudományegyetem, Egészségtudományi Kar

e-mail: jonagyorgy@de-efk.hu; ildiko.kriszbacher@etk.pte.hu; lukacsko@de-efk.hu

\section{Abstract. Managed competition - managed care.}

After the Hungarian regime change the political, economical, and social barriers reorganizing the health care system disappeared. By the middle of 1999 it was possible to adapt the American managed care model in a few counties, for example Hungary too. The Hungarian Managed Care System proved to be successful therefore more and more general practitioners and institutions joined in. In this study we present that by the introduction of the managed care program the Hungarian health care can be operated with higher efficiency.

Keywords: financing, competition, managed care, efficiency, health economics

DOI: $10.19055 / \mathrm{ams} .2010 .1 / 1 / 5$

Lektor: Dr. Kiss-Tóth Emóke Ph.D, fóiskolai tanár, Miskolci Egyetem, Egészségügyi Kar

\section{Bevezetés}

1999. július és 2009. január között Magyarországon az angol és az amerikai egészségügyi modellek alapján bevezetésre került az irányított betegellátási rendszer (továbbiakban: IBR). A területi alapon múködô rendszert kezdetben csak 
kísérleti jelleggel alkalmazták, a gyors sikerek következtében azonban évrôl-évre bôvítették mind az ellátások körét, mind a tagok számát. Az IBR céljai közé tartozott az egységes minőségbiztosítási szempontok kidolgozása, a költséghatékonyság növelése, az informatikai eszközök fejlesztése, a betegutak nyomon követéséhez szükséges elemzések készítése, a szabadabb és racionálisabb forrásallokáció, az egészségnyereség növelése, a felesleges egészségügyi szolgáltatások csökkentése, a megismételt ellátások és vizsgálatok háttérbe szorítása. Elsőszámú prioritásként jelent meg a lakosság egészségi állapotának javítása a költséghatékonyság elootérbe helyezése mellett. Fontos hangsúlyozni, hogy egy ilyen zárt, fejkvótán alapuló forrásallokációs mechanizmus bevezetése nem formálja át a jelenlegi egészségügyi redisztribúciós és finanszírozási technikát. Éppen ezért az irányított betegellátást az egészségügyi reformok tudományos kidolgozásánál mindenképp figyelembe kell venni.

Ennek az elemzésnek a célja tehát az, hogy a magyarországi irányított betegellátás (managed care) finanszírozási technikáit feltérképezze egészségszociológiai és egészség-gazdaságtani aspektusból. Megvizsgáljuk azt, hogy az irányított betegellátás forrásallokációs formulája milyen hatással volt az érintett társadalmi csoportok egészségügyi állapotmutatóira. Feltárjuk, hogy az irányított betegellátási rendszer milyen szervezeti és ellátási konstrukció segítségével volt képes költséghatékonyságot realizálni úgy, hogy közben az egészségügyi szolgáltatások minősége nem romlott. Ez egy retrospektív elemzés.

Először bemutatjuk, hogy az IBR milyen múködési sajátosságokkal rendelkezett, milyen funkcionális elvek, gyakorlatok alapján töltötte be szerepét. Ezt követően a finanszírozási technikák alapvonásait, megtérülési rátáit írjuk le empirikus adatok másodelemzése alapján.

\section{A magyar IBR müködési mechanizmusa}

Az IBR alapvetôen a brit és az amerikai egészségügyi rendszer szintetizálásaként jött létre (Donkáné - Dózsa 1999, Kincses 2007, Simon 2003, Dixon - Sweeney 2001, Birenbaum 1997). Az irányított betegellátás lényege az, hogy a beteg és az ellátást nyújtó intézmény közé egy biztosító, vagy valamilyen csoportosulás ékelődik, amely közvető funkciót tölt be a két aktor között. A közvetítés alkalmazásának előnyös hatásai gazdasági területen is manifesztálódnak, úgymint:

- nố a költséghatékonyság az ellátási színvonal csökkenése nélkül,

- racionalizálódnak a kiadások,

- a realizált megtakarításokat hatékonyabban használják fel,

- nem kerül ki az egészségügyi rendszerból a felhalmozott anyagi forrás,

- a kezelések indokoltságának kontrollja létrejön, 
- gyógyítás alatt a beteg állapota állandó ellenôrzés alatt van, végül,

- ajánlásokat fogalmaznak meg a betegút tervezésére, szervezésére.

(Kincses 2006:166)

A managed care magyarországi adaptációjának lényege úgy foglalható össze, „hogy átalány-díj ellenében a szervezô által szabályozott módon, saját, vagy szerzôdött ellátókon keresztül biztosítják az ellátást, és ez a beteg választási szabadságának valamilyen korlátozását jelenti ... Alapvetô múködési elve a piaci mechanizmus, valamint a szervezetnek, mint biztosítónak és szolgáltatónak a kettôs funkciója" (Kincses 2007: 2). Az IBR múködése során megtapasztalhattuk, hogy a magyarországi egészségügyi rendszer finanszírozásának allokációja és redisztribúciója átalakítható úgy is, hogy az nem jár többletköltségekkel és a struktúra gyökeres átalakításával (Nagy-Dózsa 2002)

Az IBR múködésében a háziorvosi rendszer központi szerepet töltött be, melynek funkciója kétirányú volt. Először is, a betegnek - ha a feltételek és betegségének jellege lehetővé tette - háziorvosával kellett először találkoznia gyógyítása során. Ha a beteget további ellátási szintre kellett továbbküldeni, akkor azt a háziorvos rendelte el, ezzel a felesleges kezelési utak elkerülhetóvé váltak, többletkiadásoktól mentette meg ezzel a rendszert és ezzel együtt minden szereplójét az orvos. A háziorvos tehát a betegutat szabályozta, irányította (kapuôr funkció), ezzel elkerülve az aszimmetrikus információ ${ }^{1}$ kialakulásából származó felesleges kiadásokat, illetve kellemetlenségeket (Boncz - Horváth 2001, Gulácsi 2005). Az IBR érdekeltségi viszonyrendszere átformálta szereplőinek gazdasági és társadalmi viselkedésformáját: a háziorvosok körében egyre elterjedtebbé vált a prevenció alkalmazása, ezzel is „távolabb tartották” a pacienseket a rendszertôl, ezáltal újabb forrásokat takaríthattak meg; az erôforrásokat a szereplők még körültekintóbben használták fel. A költségek visszafogása mellett a minôségbiztosítási struktúra egyre fontosabb lett, a költséghatékonyságra való törekvés nem hozta magával a betegek alulkezelését.

Az IBR másik - a háziorvos mellett megtalálható - főszereplője az ellátásszervezó (továbbiakban: szervezô) volt, aki a betegutak optimalizálásában volt érdekelt (Matejka 2001). A szervezó töltötte be a szolgáltatói és a finanszírozói funkciót - a biztosítás az OEP-nél maradt -, ez a kettô nem vált el egymástól. A szervezô egy virtuális folyószámlával rendelkezett, amire az OEP zárt, fejkvóta alapú finanszírozási formula által meghatározott összeget (ennek részletes bemutatását a késôbbiekben kifejtjük) átutalt, ebból kellett az ellátásokat finanszírozni és fejleszteni a hozzájuk tartozó betegek számára. Ha év végén megtakarítást ért el az elvi számlán, akkor a jogszabályban meghatározottak szerint az szétosztható volt (Marton 2004). Az IBR-nek tehát minden egyes szereplője érdekelt volt a

\footnotetext{
${ }^{1}$ Aszimmetrikus információ a beteg és az egészségügyi ellátást biztosító közötti speciális kommunikációs viszonyból származik. Az egészségügyi intézmény (eladó) többet tud a betegségról, mint maga a beteg (fogyasztó), így az egyensúlyi ár felé emelheti az általa kínált termék árát úgy, hogy közben nem veszíti el a vásárlót, nem csökken a fizetóképes kereslet.
} 
minőségi szolgáltatások nyújtásában, hiszen minél hamarabb gyógyul meg a beteg, annál kevesebbet kell költeni rá az egészségügyi kasszából. Az IBR gazdálkodásának lényege tehát az volt, hogy az OEP által folyósított összegból a törvényben meghatározott ellátást nyújtsák a lehetô legalacsonyabb költséggel maximális egészségnyereséget realizálva. A szervező ehhez saját egészségügyi intézményrendszert építhetett ki, vagy a meglévôvel lépett szerződésbe. Magyarországon ez utóbbi megoldás volt elterjedt (Sinkó 2002).

Az IBR múködése kváziverseny elvein nyugodott, ami azt jelentette, hogy a finanszírozás centralizált, állami feladat maradt, a kínálat és a kereslet közötti viszony azonban decentralizálttá vált, ezt a piaci mechanizmusok, még pontosabban az irányított verseny határozta meg (Karner, 2008, Stiglitz 2000). Így jöhetett létre az, hogy a piaci és az állami rendszerek, a szabályozói és ösztönzői funkciókat sikeresen összehangolták, ezek nem oltották ki egymás hatékonyságát, potenciálját (Barr 2009, Gulácsi - Kovács - Oesterle - Boncz 2007, Harris 2005).

A szervezó feladatait törvényben szabályozták (nem piaci folyamatok alakították), ám piaci igényekhez igazították. A szervezô legfontosabb célja volt, hogy a virtuális folyószámláján felhalmozott összegekből a legmagasabb szintú egészségügyi szolgáltatást szervezze meg a lakosság részére (Csedő - Nagy - Dobák - Dózsa Gulácsi 2003). A területi alapon szerveződő rendszer lehetővé tette, hogy a lokális egészségügyi problémák elótérbe kerüljenek - szubszidiaritás elvét alkalmazták -, azokra adekvát megoldást találjanak. A szervezố alapvetô feladata volt mindvégig a megtakarítások ésszerú allokációja, a járóbeteg ellátás erôsítése, az indokolatlanul igénybe vett ellátások számának csökkentése, a betegutak ellenőrzésének végrehajtása (Bordás 2005). 2004-tól jogszabály konkretizálta és egyben kibóvítette a szervezô funkcióit. Eszerint, a szervezô fô feladata lett a koordinálás, a prevenciós jelentések megfogalmazása, a virtuális folyószámlára érkezett összegek kezelése, a területén újabb managed care szervezeti egységek létrehozása és múködtetése, minőségbiztosítási követelményrendszerek felállítása, valamint az OEP irányába adatszolgáltatási kötelezettség teljesítése.

A szervezô az ellátottakkal együtt kiesett a rendszerből, ha egymást követő három hónapon keresztül, megszakítás nélkül deficitet realizált.

A lényegi különbség az IBR és az IBR-en kívüli struktúra között az volt, hogy ha a szervezó jól takarékoskodott, akkor a megtakarítást visszaforgathatta a rendszerbe, nem a túlköltekezésben volt érdekelt, hanem a megtakarításban, amelyból kizárólag fejlesztési célokat valósíthatott meg (Gilly - Szabó 2004a, 2004b). A szervezô tehát a kemény költségvetési korlát alkalmazását preferálta, racionálisabb forrásallokáció valósult meg a hatékonyság, a szolidaritás és a méltányosság együttes szem elótt tartásával (Kornai 2008).

Az IBR céljai közé sorolható az egységes minôségbiztosítási szempontok kidolgozása, költséghatékonyság növelése, az informatikai eszközök fejlesztése, a betegutak nyomon követéséhez szükséges elemzések készítése, szabadabb és racionálisabb forrásallokáció, az egészségnyereség növelése, a felesleges egészségügyi szolgáltatások csökkentése, a megismételt ellátások és vizsgálatok háttérbe szorítása. El- 
sőszámú prioritásként jelent meg a lakosság egészségügyi állapotának javítása a költséghatékonyság előtérbe helyezése mellett. Egyértelmú célként deklarálták, hogy a lakosság egészségnyereségét maximalizálni kell a gazdálkodás hatékonyságának szem előtt tartásával. Az érintett területen élő lakosság hatékony egészségügyi szolgáltatásának megszervezése, definitív ellátások nyújtása, a morbiditási és mortalitási indikátorok javítása, a betegút-követéssel számos újabb faktor is megismerhetôvé vált a betegség diagnosztizálásához, illetve annak gyógyításához. Ugyanakkor a párhuzamos kezelések háttérbeszorítása princípiumként jelent meg az IBRben, mely többnyire az egészségügyi informatikai rendszer modernizációjával megvalósíthatóvá vált (Kerekes 2003).

Ezek eléréséhez a legfontosabb módszerek a következók voltak: prevenció favorizálása, egységes ellátási protokoll definiálása, valamint a háziorvosok közötti kapcsolat erôsítése. Röviden: az IBR-t a racionálisabb és szabadabb forrásallokáció egyik eszközeként alkalmazták, ezáltal korlátozott formában teret nyert a kemény költségvetési korlát (Kornai 1998, 2004).

Az IBR keretei között a következó ellátások szerepeltek: háziorvosi és házi gyermekorvosi ellátás, gyógyfürdő-szolgáltatás, fogászati ellátás, gyógyászati segédeszköz támogatás, gondozóintézeti gondozás (2004-tôl), betegszállítás orvosi előírásra (2004-tôl), gyógyszertámogatás (törvényben meghatározott gyógyszerek kivételével mindegyikre vonatkozott), járóbeteg-szakellátás, fekvóbeteg-szakellátás, házi szakápolás, múvesekezelés, CT/MRI. Az IBR kizárólag természetbeni szolgáltatásokat tartalmazott, pénzbeli támogatásokat nem (Matejka 2004).

Az IBR bevezetésének indokoltságát Mikola azzal támasztotta alá, hogy „Magyarországon - az európai trendekkel egybevágóan - olyan menedzselt betegellátást kell kialakítani, amely garantálja a nemzeti egészségmegórzési célok megvalósítását, a közösségek egészségének javítását, a betegségek korrekt kezelését és a betegközpontú ellátást. A menedzselt betegellátás egyensúlyt teremthet az egészségügyi szolgáltatások és a korlátozott források között. Ennek érdekében esetról-estre monitorozza a tevékenységet, és a nyert adatokat a szolgáltatás optimalizálása érdekében használja. E funkciójában valójában az állami egészségpolitikát is közvetíti, tehát ötvözi a különbözô menedzsmentszinteket." (Mikola 1998: 15)

Megint máshol ezzel kapcsolatban azt olvashatjuk, hogy „az irányított betegellátást megvalósító modellek mindenképpen előre mutató, közös eredôje, hogy megteremtik azt az ellátásszervezôt - a multidiszciplináris egészségügyi menedzsmentet -, amely érdekelt a költségek jobb felhasználásában, ehhez optimalizálja a betegkezelést és a beteg útját az ellátás teljes vertikumában." (Nagy-Dózsa 2002: 58)

\section{Az IBR finanszírozási technikája}

Az IBR-be csak önkéntesen, pályázat útján lehetett bekerülni. Nem terjedt ki az egész országra, csupán néhány városra, illetve annak háziorvosára vagy kórházára. $\mathrm{Az}$ adott területhez tartozó egészségügyi intézmények és háziorvosi praxisok élén a szervezô állt, aki egy virtuális folyószámlával rendelkezett, amit az OEP finanszíro- 
zott. Ez valóban egy virtuális folyószámla volt, amin csupán év végén lehetett realizálni a megtakarítást vagy a deficitet. A virtuális folyószámla tehát nem volt más, mint egy, a szervező tulajdonában lévő, nyilvántartás, amelyen a bevételeket és a hozzá tartozó lakosok egészségügyi szolgáltatásokkal járó kiadásait adminisztrálták. Az IBR finanszírozását a 43/1999. (III.3) Kormányrendelet szabályozta.

A megtakarítások felosztása jogszabályokkal volt körülbástyázva annak érdekében, hogy ne lobbycsoportok érdekérvényesítő-képességének, hanem centralizált keretek között történjen a redisztribúció. A megtakarítási keret redisztribúciója során nem csak a realizált profitot vették figyelembe, hanem az alábbiakat is:

- A prevenciós tevékenység végrehajtása mennyire volt eredményes,

- Az előző finanszírozási évhez való fejlődés, növekedés mértéke mennyit változott,

- A lakosság számát,

- A szervezô elôzô évi virtuális folyószámlájának egyenlegét,

- A háziorvos adatszolgáltatási kötelezettségének betartatását.

A virtuális folyószámlára érkezô összeget rizikótényezôvel korrigált fejkvóta alapján határozták meg, amit három tényezóvel korrigáltak: nem, kor (8 korcsoportot különítettek el) és a múvesekezelések jellege - ez utóbbi tényezôvel 2002-ben egészítették ki a formulát. 2005-től retrospektív formában végezték a múvesekezelések finanszírozását. Vagyis, 8 korcsoport, 2 nem és 2 múveseváltozó volt érvényben, tehát $(8 \times 2 \times 2=32) 32$ cellára volt bontható a finanszírozási táblázat. A múvesekezelés jogcím alá tartozó kezelésekre szánt összeg 7,5 százalékát akut múvesekezelésre, 92,5 százalékát pedig krónikus múvesekezelésre fordították - e kettô eltérô fejkvóta szerint került finanszírozásra.

A korcsoportok az alábbiak szerint oszlott meg:

1. 0-4 évesek,

2. 5-14 évesek,

3. 15-34 évesek,

4. 35-50 évesek,

5. 51-60 évesek,

6. 61-70 évesek,

7. 71-80 évesek,

8. 81 éven felüliek. 
Az IBR finanszírozása során zárt, fejkvótán alapuló elszámolási formulát alkalmaztak (Nagy- Dózsa - Boncz 2004). Ennek összegét részben az előzô év azonos időszakának előirányzatai alapján definiálták, ekkor még csak a nem és a kor alapján számították a fejkvóta összegét. Erre azért volt szükség, mert ahol magas egészségkockázati tényezók vannak, oda nagyobb összegeket kellett csoportosítani, és fordítva. Ennek figyelembevételével olyan forrásallokációs mechanizmusok érvényesíthetők, melyek segítségével az egészségügyi ellátórendszerben megtalálható forrásokat stratégiailag hatékonyabban és igazságosabban lehetett szétosztani az ellátások szinte minden szintjén - persze, ha nem is minden területen, de a legtöbb részen (Todd 2009, Rácz 2003).

Az IBR-ben alkalmazott fejkvóta alapú finanszírozási rendszer gyakorlati kialakítása az alábbi lépések szerint történt:

1. Elsôként az elôzô év hasonló periódusában lévô ténylegesen felhasználható adatokat (népesség száma nem és kor szerinti megoszlásban) gyưjtötték össze. Ez a Központi Statisztikai Hivatal adatbázisából könnyen beszerezhetô volt.

2. Ezt követően az elôző év hasonló időszakában hónapról-hónapra a fent leírt 8 korcsoport alapján besorolták a teljes lakosságot. Például, 2004. januárjában (elôzố év adott hónapja) a 15-34 év (kor) közötti férfiak (nem) a teljes népesség 7,93\%-át tették ki. A továbbiakban e logika szerint a teljes lakosság bekerül ebbe a felosztásba.

3. Majd megállapították, hogy az előző év hasonló időszakában a háziorvosok mennyit költöttek adott nemre és korcsoportra. Például, 2004. januárjában a 15-34 év közötti férfiak ellátására 270.440.858 Ft-ot költöttek el.

4. A következókben összevetették ezt az adatot a nem- és korcsoportonkénti országos létszámadattal. Ez azt jelenti, hogy 2004. januárjában a 15-34 év közötti férfiak háziorvosi ellátására 270.440.858 Ft-ot költöttek, ehhez a korosztályhoz pedig 1.505.520-an tartoztak, így ezt a két számot egymással elosztották (a felhasznált összeg osztva az adott kategóriába tartozók számával). Így kapták a 179,63 Ft-os indexálatlan fejkvótát ennél a korosztálynál. Ezt hasonló módon minden egyes kategóriánál végigszámolták.

5. A fejkvóta pontos kiszámításához indexszámot képeztek, amit az adott kassza elôző év tény szerinti kifizetése és az elôirányzat aránya (ténykifizetés osztva az előirányzat összegével) alapján számítottak ki. Minden egyes nem- és korcsoporthoz külön indexszámot rendeltek.

6. Végül, a nem- és korcsoportokra osztott kategóriákhoz hozzárendelték az adott indexszámot, így megkapták a végleges indexált fejkvótát. Például, 2004. januárjában a 15-34 év közötti férfiaknál 179,63 Ft-os indexálatlan fejkvótát számítottak (lásd a 4. pontot), aminek az indexszáma 1,0211. Az indexált fejkvóta itt tehát 183,43 Ft volt. 
Csak késóbb (2002-ben) emelték be a múvesekezelés jellege tényezôt is a fejkvóta kiszámítási egyenletébe, amely mint diagnózis alapú kockázati faktorként jelent meg a rendszerben. A krónikus és akut múvesekezelés finanszírozása megoszlott, ezért ezeket külön mutatjuk be. Az akut múvesekezelés fejkvóta számításánál a fent említett 8 korcsoport és 2 nem alapján az előzó évi teljesítményadatokat vetették egybe. Ennek az adatnak a 7,5\%-át határozták meg nem és kor szerint. Például, 16.118.900.000 Ft-ot költöttek 2004-ben vesekezelésre. Ennek 7,5\%-át csoportosították akut múvesekezelésre, amit havonta nem és kor szerinti bontásban kaptak meg a szervezók.

A krónikus múvesekezelés során a teljes tárgyévi előirányzati összeg fennmaradó 92,5\%-át osztották fel 12 (az év 12 hónapból áll) részre. Ezt a havonkénti összeget még tovább differenciálták nem és korosztály szerint (Boncz - Dózsa - Gulácsi 2004).

Az IBR-ben az elszámolás nem volt azonos az utolsó naptári nappal, minden év szeptember utolsó napja jelentette az elszámolási periódus végét (Boncz - Dózsa 2003).

A szervezők év végi veszteségének kezelésére speciális pénzügyi alapot, úgynevezett kiegyenlítő kasszát hoztak létre 2003-ban. Ebból az alapból azoknak a szervezóknek a veszteségeit kompenzálták, akik nem tudtak a bevételi forrásokból megtakarítást realizálni.

Az IBR finanszírozása tehát több csatornán keresztül történt, az ellátásszervezők virtuális folyószámlája a következő tételek alapján rekrutálódott:

- A fejkvóta szerinti összeg az OEP részéról,

- A prevenciós és szervezési díjak,

- Egyéb pályázatok.

2005-tôl újabb változások mentek végbe ezen a területen. A szervezó bevételhez jutott:

- prevenciós díjból (erról részletesen a késóbbiekben),

- megtakarítási kifizetésból (az előző évi többletből folyósították egy részét),

- szervezési díjból (errôl részletesen a késóbbiekben),

- a fejkvóta szerinti összeg az OEP részéról,

- szervezói alap kifizetéséból, mely a szervezóknek nyújtott, kifejezetten fejlesztésre és egészségügyi innovációra fordítható összeg volt. Ebból az egészségügyi informatikai infrastruktúrát lehetett modernizálni, valamint létszám stabilizációt megvalósítani,

- egyéb pályázatok. 
Az IBR finanszírozásának metodikája meglehetősen egyszerünek tekinthető, mégis eredményes volt. 2005-ben az Egészségügyi Minisztérium a következôket fogalmazta meg ezzel kapcsolatban: „Az IBR elszámolásának kulcselemét képző fejkvóta számításának technikája és módszertana - bár az utóbbi évek során fejlődést mutatott - további korrekciót igényel megfelelő szakértők és tudományos múhelyek bevonásával és forrás biztosításával ... A fejkvóta korrekciós lehetôségek modellezését el kell végezni, melyhez szintén szükséges megfelelő kutatói háttérkapacitás biztosítása ... A tevékenység végzésére az IBR további sorsától függetlenül is szükség van a jelenlegi rendszer forráselosztásban mutatkozó területi egyenlőtlenségeinek csökkentését szolgáló programok kidolgozásához." (EÜM 2005)

Az IBR finanszírozásánál a prospektív és retrospektív elosztási modelleket egyszerre alkalmazták, ezek szintézisét használták. Ez azt jelentette, hogy a demográfiai adatoknál prospektív (a már meglévő, több évi adatsorból a következó évi költségvetési számokat becsülték meg), az ellátásoknál pedig retrospektív (kizárólag a becslési évben megszerzett adatokat használták) finanszírozási módot vették figyelembe.

Az IBR finanszírozási formulája lehetôséget nyújtott arra, hogy a magyar egészségügyi rendszerben megfigyelhetô finanszírozási polarizáltság háttérbe szoruljon. Mivel az egészségügyi kasszák elkülönültsége okozta a legnagyobb hátrányokat a rendszerben, az IBR éppen ezt a problémát oldotta meg azzal, hogy az elkülönült kasszákat „összenyitotta”. „Az egyes kasszák összenyitása és közös finanszírozása egy szükségletekhez igazított fejkvóta formula használatával jelentôsen növelhetné az allokációs hatékonyságot és ugyanakkor a méltányosságot is sok területen. Egy új fejkvótán alapuló stratégiai forrásallokációs formula nem kell, hogy feltétlenül megváltoztassa a jelenlegi finanszírozási gyakorlatot. Ilyen rendszer bevezetése óvatosságot, gondosságot és fokozatosságot igényel. Kezdetben csupán jó támpontot adhat a források allokációja kívánatos arányának megállapításához, késóbb esetleg a finanszírozási rendszer továbbformálásának egyik alternatívája lehet." (Nagy 2006: 14) A forrásallokációs hatékonyság gyors mértékben emelkedett. Az IBR egy olyan ellátásszervezés formát jelentett, ahol a szolgáltatások finanszírozási integrációja 90 százalékban megvalósult. A betegutak helyes szervezésével az ellátási szintek finanszírozási integrációja létrejött, így nem helytálló az a bírálat, mely szerint a szervezố kiveszi a megtakarítást akkor is, ha bizonyos kasszák deficitet realizálnak. Valahol deficites, máshol szufficites a kassza, ezért kell „összenyitni” azokat, így a betegellátás irányítottá, jól szervezetté válik és nem feltétlenül igényel több forrást (Boncz - Horváth - Jónásné - Dózsa 2004). Az érdekeltségi viszonyok is átrendezóztek a korábbi struktúrához képest, a finanszírozó és a szolgáltatást nyújtónak (vagyis a szervezónek) érdekévé vált a források racionális visszafogása. A sajátos pályáztatási rendszer garantálta azt, hogy minden háziorvoshoz tartozó beteget ellássanak, lefölözés ${ }^{2}$ nem alakulhatott ki (Mihályi 2003).

\footnotetext{
${ }^{2}$ Lefölözésrôl akkor beszélünk, amikor a biztosító társaságok szabadon válogathatnak a biztosítottak között. Nyilvánvaló érdekük, hogy olyan személyekkel kössenek biztosítást, akik egészségesek, fiatalok, nincs káros szenvedélyük, stb. tehát egészségesek. Az ô ellátásuk olcsó lenne, vagy
} 
Az IBR-ben a háziorvosok automatikusan, a rendszer jellegéból adódóan, érdekeltek voltak a megtakarításokban, hiszen ebból ók is részesedtek premizálás során, a betegutakról teljes körú információt szereztek és a prevencióban is központi funkciót láttak el. A szakrendelők is részesültek a megtakarításokból, mely a belsô kontrollt erôsítette - a háziorvosokkal való együttmúködés pedig a külsô kontrollt jelentette számukra. A kórházak szintén kaptak támogatást a megtakarításokból, hiszen részt vettek a gyógyító munkában. A megnoott háziorvosi kontroll miatt a gyógyszertárak és a gyógyszergyárak nem tudták az indokolatlan gyógyszerfogyasztást fenntartani, az erkölcsi kockázat visszaszorulása ezen a területen volt a legkiemelkedőbb (Boncz 2004, Kornai 2004: 52-53, 57). A betegek szintén preferálták az IBR-t, mert benne a prevenciós tevékenység felerősödött, egészségi állapotuk javult (volt olyan terület, ahol az érintettek 53\%-a leszokott a dohányzásról). Az önkormányzatok is támogatták az IBR-t, mert számos feladatot automatikusan átvett tôlük. Ez az érdekeltségi viszonyrendszer ösztönzést jelentett a managed care fenntartásában és finanszírozásában minden érintett számára (Orosz 2001). Az IBR-en kívül majdnem minden szereplố az egészségügyi szolgáltatások túlzott igénybevételében volt érdekelt, az IBR-ben azonban már maguk a betegek, szervezôk és a finanszírozó együtt törekedtek arra, hogy az ellátások igénybevétele túlzottá ne váljon (Kongstvedt 2001, 2007, 2008).

Végsố soron az IBR-ben és az IBR-en kívüli ellátórendszer finanszírozásának különbsége az volt, hogy az IBR-ben irányított versenyhelyzetet teremtettek, ami az elosztható forrásokat némileg átalakította (Gabe - Calnan - Bury 2009, Moseley 2008). A másik eltérés az volt, hogy a zárt, fejkvóta alapú finanszírozási formula földrajzi-területi alapon osztották szét. „Az új ellátás-finanszírozási rendszermodell gyakorlati megvalósulása során a források szétosztása - egy szervezô segítségével - jól körülhatárolt földrajzi környezetben alkalmazott fejkvóta alapú rendszer kereteibe ágyazottan történik. Ez hatékonyabb, a helyi szükségleteket az eddiginél jobban figyelembe vevô egészségügyi szolgáltatások nyújtásának lehetôségét teremti meg." (Minisztériumi Zárszámadás 2002: 13)

\section{A prevenciós tevékenység finanszírozása}

Az IBR-ben prevenciós díjakat kizárólag azok a szervezók kaptak, akik legalább egy évre vonatkozó prevenciós tervet készítettek és ezt adott év márciusáig benyújtották az OEP számára. Ez egy igen részletes program volt, mely nemcsak a prevenciós célokat, hanem a hozzájuk tartozó eszközöket, módszereket és költségvetési tervet is tartalmazta. Ha a prevenciós programot megvalósíthatónak tartotta az OEP, akkor a szervezó prevenciós díjat kapott, amely kizárólag a koncepcióban meghatározott célok és eszközök fedezetére szolgált.

A prevenciós díj összege az IBR bevezetésekkor 1000 Ft/fő/év, 2001-tôl azon-

éppen semmibe sem kerülne. A beteg egyénekkel nem áll érdekükben biztosítást kötni, hiszen az ő ellátásuk drága volna. A költséges ügyfelek kiválogatása, „lefölözése” a cél a biztosítók esetében, ám a világon szinte mindenhol ezt állami jogszabályokkal részben vagy egészben meggátolják. 
ban ez az összeg kettévált, 500 Ft prevenciós díjat és 500 Ft szervezôi díjat kapott a szervezô évente egy ellátott után. A következő évi költségvetési törvény értelmében a prevenciós tevékenység finanszírozása újból átalakult: ha a szervező már adott területen több mint egy éve nyújtott prevenciós ellátást, akkor a második év után csökkentett, vagyis $200 \mathrm{HUF}$ /fő/év szervezési díjra volt jogosult. A prevenciós díjat két évig, a szervezési díjat egy évig folyósították. A prevenciós díjat negyedévente, a szervezési díjat havonta folyósította az OEP a szervezô virtuális folyószámlájára. 2005-tól azonban a prevenciós díj mértékét 600 Ft/fő/évben állapították meg. Prevencióra természetesen ennél magasabb összeget is fordíthattak a szervezók, hiszen megtakarításaiknak adott hányadát átcsoportosíthatták ide, valamint más (akár nem állami) pályázati forrásokat is megszerezhettek. Az I. táblázat azt mutatja meg, miként alakult a prevenció finanszírozása az IBR-ben.

I. táblázat - Szervezôk részére kifizetett szervezési és prevenciós díjak

\begin{tabular}{c|c|c|c|c} 
Időszak & Prevenciós díj & Szervezési díj & $\begin{array}{c}1 \text { före jutó } \\
\text { prevenciós díj } \\
(\mathrm{Ft})\end{array}$ & $\begin{array}{c}1 \text { före jutó } \\
\text { szervezési díj } \\
(\mathrm{Ft})\end{array}$ \\
\hline 1999 & $724.544,00 \mathrm{e}$ & 0 & 508,03 & 0 \\
2000 & $73.259,40 \mathrm{e}$ & 0 & 828,25 & 0 \\
2001 & $222.443,30 \mathrm{e}$ & $121.779,70 \mathrm{e}$ & 583,43 & 547,46 \\
2002 & $227.694,60 \mathrm{e}$ & $101.307,30 \mathrm{e}$ & 478,30 & 444,93 \\
2003 & $279.773,40 \mathrm{e}$ & $64.147,20 \mathrm{e}$ & 464,81 & 229,38 \\
$2004^{*}$ & $592.496,00 \mathrm{e}$ & $424.297,00 \mathrm{e}$ & - & - \\
$2005^{*}$ & $1.114 .835,70 \mathrm{e}$ & $643.327,80 \mathrm{e}$ & - & - \\
$2006^{*}$ & $311.800,00 \mathrm{e}$ & $104,500,00 \mathrm{e}$ & - & -
\end{tabular}

Forrás: Belicza - Boncz - Horváth - Jónásné 2004: 224.

* Saját számítás - J. Gy.

A szervezési és prevenciós díjak megfelelő elköltését számlákkal kellett bizonyítani az OEP számára. A szervezési díj közvetve kapcsolódott a prevenciós tevékenységhez, ebból fizették a minőségbiztosítási rendszerrel kapcsolatos kiadásokat, a betegút követő informatikai rendszer kialakítását (KIBIR), az IBR szakmai protokoll kidolgozását. A prevenciós és szervezési díj felhasználását az OEP félévente ellenórizte.

Prevenciós díjban részesülhettek olyan „külsô” szakemberek, illetve vállalkozók is, akik nem voltak állandó tagjai az irányított betegellátásnak, csupán adott munkára szerződéses viszonyba kerültek az IBR-rel. Erre csak akkor kerülhetett sor, ha a prevenciós program teljes körú megvalósításához a rendszeren belül nem találtak kellő módon felkészült szakembert, illetve ha nem költséghatékonyan tudták volna elvégezni a prevenciós tevékenységet az IBR-en belül. Szerződést csak akkor jöhettek létre külső taggal, ha az OEP Irányított Betegellátási Foósztálya ehhez írásban hozzájárult. 
Szervezési díjat kizárólag az ellátással és szervezéssel kapcsolatos kiadásra lehetett költeni. Szervezési díjra a szervezó az alábbi tevékenységek elvégzéséért volt jogosult:

- Informatikai rendszerek fejlesztése, azok kialakításának támogatása,

- A hozzá tartozó ellátotti kör számának megtartása, illetve további növelése,

- Az újabb, késóbb bekapcsolódó praxisok felzárkóztatása az adatszolgáltatásokkal összefüggésben,

- Jelentési kötelezettségek elküldésére vonatkozó kiadások finanszírozása.

A prevenciós tevékenységrôl negyedévente a szervezônek szöveges értékelést kellett készíteni az OEP számára, az évenkénti beszámolónak azonban már nem csak kvalitatív elemzéseket, hanem kvantitatív adatokat is kellett tartalmaznia. Az évenkénti jelentéshez kapcsolódó adatfelvételénél nem egyforma kérdőívet alkalmaztak a szervezók, így az ezekből származó eredmények összehasonlítása nehéz vagy lehetetlen. Ha az OEP szakértői bizottsága nem fogadta el az évenkénti prevenciós jelentés értékelését, akkor megvonták a prevenciós és szervezói díjat is, erre azonban egyszer sem került sor.

2006. január 1-tôl végleg megszünt a prevenciós díj és a szervezési díj.

Az IBR-ben a prevenció filozófiája ellentétes irányú volt az IBR-en kívüli prevencióval. Míg az utóbbi betegségorientált, az IBR egészségorientált szemléletet követett - minden résztvevôje abban érdekelt, hogy a lakosság egészséges maradjon. Finanszírozási rendszere is erre motivál minden szereplôt. Az érintett lakosság elemi érdeke volt egészségesként élni, hiszen a betegség nem csak testi, de pénzben kifejezhetô károkat is okoz. Emellett a szervezônek is érdeke volt a hozzá tartozó lakosság egészségben tartása, mert ezzel költséges kórházi ellátásokat tudott megtakarítani.

Az IBR-ben a prevenció fogalmát a következóképpen definiálták: prevenciónak tekintették mindazon cselekvések összességét, melyek a betegségek kialakulásának megelôzésére, annak felismerésére, a későbbi károsodások bekövetkezésének elkerülésére irányultak. A prevenciónak három szintjét különböztették meg egymástól: Primer prevenció az egészség fenntartására, a betegségek kialakulásának elkerülésére és az egészséges állapot fenntartására, annak további menedzselésére vonatkozó tevékenységek összességét jelentette. Eszközei és módszerei közé tartozott az egészségnevelés, az immunizáció, a környezeti egészségkárosító tényezók megszüntetése, illetve annak háttérbe szorítása, az életmód kedvezó irányba történó befolyásolása, a rizikó állapotok szúrése. Az IBR szervezói már a program kezdetén arra törekedtek, hogy az általános iskolai kortól elkezdjék az egészséges életmódra való nevelést, így ezeknek az oktatási intézményeknek ebben nevelési és pedagógiai támogatást nyújtottak. Emellett, klubokban rizikócsökkentó programokat tartottak, melyek megvalósításában civil szervezetek segítettek. Itt főként a dohányzás, elhízás és a mozgásszegény életmód káros hatásainak felismertetése volt a cél. Ilyen 
klubokba összesen 23.000-en jártak az IBR múködése során. Volt olyan terület, ahol a klub prevenciós tevékenysége következtében a klubtagok 53\%-a leszokott a dohányzásról, mely nemzetközileg is komoly eredményként fogható fel.

Secunder prevenció a korai fázisban lévő betegségek felismerésére irányuló tevékenységeket jelentette, amikor a betegségben még visszafordíthatatlan átalakulások nem mentek végbe. Eszközei és módszerei a következók voltak: különbözó szûrốvizsgálatok és az utánuk következô gyógyító beavatkozás. Az IBR prevenciós programját általában a szûrésekre vonatkozó adatok alapján operacionalizálták (hányan mentek el szúrésre, a szűrôvizsgálatok után hány embert szürtek ki, hányat vettek gondozásba). A kiemelten kezelt szúrések közé tartoztak:

- Cardiovasculáris megbetegedések szúrése (secunder prevencióban ezt preferálták legeróteljesebben),

- Légzôszervi megbetegedések szûrése,

- Vesemúködés, húgyúti megbetegedések szürése,

- Alzheimer-kór szưrése,

- Mozgásszervi megbetegedések szúrése,

- Colorectális szûrés,

- Életmódbeli rizikótényezôk szûrése,

- Légúti szúrés,

- Mozgásszervek fizikális vizsgálata.

Tercier prevenció jelentése az IBR-ben az alábbiak szerint foglalható össze: a prevenció során felfedezett betegségekból származó károsodások, szövôdmények megelőzése. Ha a prevenció által valamilyen betegséget kiszürtek, akkor annak kezelésére is nagy hangsúlyt helyeztek - nem csupán a betegségek felismerése volt a cél, hanem annak kezelése is. A tercier prevenció eszközei és módszerei közé sorolható a gondozás keretében zajló a tanácsadás, az életmód-oktatás, valamint a kontrollált ellátás. A tercier prevenció által kiszúrt beteget gondozás alá kellett helyezni. Ez azt jelentette, hogy a háziorvos ellátásban részesíti, szükség esetén az egészségügyi rendszer más, magasabb szintjeire továbbküldi a kiszûrt beteget. A prevenciós szolgáltatások körében a háziorvos kapuôr funkciója megerôsödött, ố maradt a rendszer központi szereplője, munkáját késóbb gyakrabban segítették non-profit szervezetek is.

A tercier prevenció az IBR-ben majdnem a gondozással volt azonos. A gondozásra vonatkozó adatok - logikusan - megkülönböztetik a gyermek és a felnôtt populációt, így a preventív szemléletmód erôsödése nem csak a felnôtt háziorvosok, hanem a gyermekorvosok körében is megfigyelhető volt. A területileg IBR-be tartozók életkortól függetlenül 12,4\%-a vett részt folyamatos és eseti szúrésen. 
A késóbb belépó szervezók is hamar felhívták a háziorvos figyelmét a tercier prevenció fontosságra, a gondozásba vett személyek aránya három hónap alatt 13 százalékponttal emelkedett. A hypertoniás gondozottak aránya elérte a 20-24 százalékot az IBR-ben, számuk évról-évre nőtt.

Az ischaemiás szívbetegség előfordulása a magyar lakosság körében 5-6 százalékban fordul el, az IBR-be tartozók közül ilyen, vagy még nagyobb arányban is gondozásba vettek betegegeket.

A prevenció hármas szintjei szisztematikusan épültek egymásra, így ezek integrált egységet alkottak.

\section{Az IBR szabályozási és megvalósítási gyakorlata, egészség-gazdaságtani eredményeinek elemzése}

Az IBR-be 1999. elején pályázat útján lehetett bekerülni. Nem terjedt ki az egész ország területére, csak azokra az egészségügyi szervezetekre, háziorvosokra és a hozzá tartozó ellátotti körre, akik pályázatukat benyújtották. Rájuk is csak kísérleti jelleggel vonatkozott az első időszakban. Az érintett lakosság a háziorvossal kötött szerzôdés alapján tagolódott be a rendszerbe. A csatlakozott egészségügyi szereplók munkáját adott területen egy szervező koordinálta.

Az indítás utáni években újabb pályázatokat is kiírtak, így az IBR-hez tartozók száma igen gyors növekedésnek indult, errôl a II. táblázat nyújt átfogó információt.

II. táblázat - Az IBR résztvevőinek száma adott évben

\begin{tabular}{l|r|r} 
Időszak & $\begin{array}{r}\text { Érintett } \\
\text { lakosok } \\
\text { létszáma }\end{array}$ & $\begin{array}{r}\text { Résztvevô } \\
\text { praxisok } \\
\text { száma }\end{array}$ \\
\hline 1999. július & 158.984 & 103 \\
1999. október & 88.232 & 91 \\
2000. január & 199.882 & 55 \\
2000. december & 493.076 & 333 \\
2001. június & 474.630 & 298 \\
2001. október & 476.737 & 298 \\
2002. szeptember & 970.393 & 635 \\
2003. július & 955.829 & 624 \\
2003. október & 1.112 .861 & 720 \\
2004. március & 1.888 .574 & 1240 \\
2004. szeptember & 2.279 .513 & 1495 \\
2005. július & 1.689 .927 & 1090 \\
2006. szeptember* & 912 \\
2007. január* & 1.417 .485 & 898 \\
2007. december* & 1.393 .287 &
\end{tabular}

Forrás: Belicza, É. - Boncz, I. - Horváth, Á. - Jónásné Katona, K. 2004: 14 * Adott év Pénzügyminisztériumi Zárszámadása. 
Már az induló években sikerült profitot realizálni, ami késóbb még további emelkedést mutatott. Ennek alakulásáról a II. számú táblázat ad felvilágosítást.

Nem sokkal az indítás után az IBR által használt fejkvóta eredményességét empirikus vizsgálatnak vetették alá. Ez a kutatás arra világított rá, hogy az IBR számára átutalt összegek közel 77 százalékát az ellátottak csak 10 százaléka veszi igénybe (Pénzügyminisztériumi zárszámadás 2001: 17). Az egyértelmú forrásfelhasználási egyenlőtlenségeket a fejkvóta allokációs hatása helyesen kezelte (Mihályi 2005).

III. táblázat - Az IBR megtakarításai

\begin{tabular}{l|r|c} 
Év & Megtakarítás összege & $\begin{array}{c}\text { A bevétel hány } \\
\text {-a lett felhasználva }\end{array}$ \\
\hline 1999 & $63.138,00 \mathrm{e} \mathrm{Ft}$ & Nincs adat \\
2000 & $475.662,60 \mathrm{e} \mathrm{Ft}$ & $89,60 \%$ \\
2001 & $1.109 .442,30 \mathrm{e} \mathrm{Ft}$ & $93,46 \%$ \\
2002 & $2.710 .926,90 \mathrm{e} \mathrm{Ft}$ & $91,27 \%$ \\
2003 & $1.170 .995,70 \mathrm{e} \mathrm{Ft}$ & $96,58 \%$ \\
$2004^{*}$ & $3.273 .518,00 \mathrm{e} \mathrm{Ft}$ & $96,99 \%$ \\
$2005^{* *}$ & $3.709 .449,51 \mathrm{e} \mathrm{Ft}$ & $97,90 \%$ \\
$2006^{* *}$ & $4.964 .574,70 \mathrm{e} \mathrm{Ft}$ & $89,99 \%$
\end{tabular}

Forrás: Belicza, É. - Boncz, I. - Horváth, Á. - Jónásné Katona, K. 2004. *A megtakarítás ebben az évben azért esett vissza ilyen nagymértékben, mert ekkor hirtelen nőtt az új belépók aránya, nekik csupán 3 hónapjuk maradt, hogy hasznot produkáljanak. Nyilvánvalóan ez kevés időnek bizonyult, a megtakarítások nem tudtak ilyen rövid idô alatt megnóni. ** Saját számítás - J. Gy.

A táblázatokban szereplő számok alapján kijelenthetô, hogy az IBR makroszinten költséghatékony volt, nem igényelt több forrást, mint az IBR-en kívüli ellátás. A managed care elv Magyarországon kedvezô hatást gyakorolt az egészségügyi szektorra, a társadalomra és a gazdaságra egyaránt. Mindezek ellenére az IBR múködésének elsô szakaszában az egészségügyi rendszer vezetôinek elismerését váltotta ki, majd késôbb ez megfordult.

2004. szeptemberében az OEP még pályázatot írt ki, amely 7 új szervezô bevonását jelentette. Így ugrott meg hirtelen az ellátottak, a praxisok és a szervezôk száma.

2005-ben a költségvetési törvény értelmében egy szervezôhöz minimum 100.000, maximum 450.000 fố kerülhetett, de a rendszerben összesen maximum 2.5 millió fô lehetett benne. Egy egész kistérség a szervezóhöz került akkor, ha a kistérség minimum 70 százaléka az IBR-hez tartozott (70\%-os szabály). Az elvi folyószámla finanszírozását ekkor úgy kellett megállapítani a szervezô számára, mintha az egész kistérség hozzá tartozna. 
A megtakarítások szétosztásának szabályozása is egyre kedvezótlenebbé vált a szervezóknek néhány év elteltével. A kezdeti periódusban ha a bevétel 10 százalékát vagy annak kisebb arányát takarítják meg egy évben, akkor ennek az összegnek csak a 80 százaléka volt szétosztható, a fennmaradó 20 százalékot az OEP számára kellett visszaküldeni. Ha a megtakarítás a 10 százalékot elérte vagy annál nagyobb arányú volt, akkor 10 százalékot kitevô összeg 80 százalékát, a 10 százalék feletti megtakarított összegnek pedig 50 százalékát lehetett az IBR-be visszaforgatni. (Zárójelben jegyezzük meg, hogy a szervezók évenként különbözó arányú bevételi többletet mutattak fel, amit haszonként osztottak szét az egészségügyi rendszerben. A megtakarítások mértéke területenként nagy eltérést mutatott, melyek okait mélyebb empirikus vizsgálat még nem tárta fel.)

2007-től a felosztás degresszív szabályai újból átalakulnak: ha a szervezô a bevétel 10 százalékát vagy annál alacsonyabb mértékú megtakarítást könyvelte el, akkor ennek az összegnek a 30 százaléka vált szétoszthatóvá a korábbi 80 százalék helyett. Ha a megtakarítás aránya túllépte a 10 százalékot, akkor 10 százalékig terjedô rész 30\%-a, az afeletti résznek pedig a 25 százaléka vált eloszthatóvá a korábbi 50 százalék helyett. Ez jelentôs mértékben csökkentette az elosztható források körét, ezzel - logikusan - az ösztönzés is mérséklődött.

A felhalmozott megtakarítás maximum 40\%-a kerülhetett a háziorvosokhoz, a járóbeteg-ellátásban résztvevôk 10\%-ban, a fekvôbeteg-ellátásban résztvevôk szintén 10\%-ban részesültek belőle. A prevenciós és háziorvosi ellátásokra további összegek voltak átcsoportosíthatók, amelyeket kellő alapossággal kellett indokolni az OEP-nek. 2004-tól azonban az elosztás során a megtakarítás 30\%-át a háziorvosoknak, 15-25\%-ot a járó- és fekvóbeteg ellátóknak, 10\%-át az informatikai szolgáltatóknak folyósították, $25 \%$ a szervezônél marad.

2006-ban a háziorvosi praxisokhoz kapcsolódó források kiestek az IBR-ból, mert a 331/2005. (XII. 29.) kormányrendelet szerint a háziorvosi praxisok megszûntek létezni az IBR keretében.

2007-ben kötelezôvé tették az ellátásszervezô számára, hogy háziorvosok segítségével a hozzá bejelentett biztosítottakat értesítsék IBR tagságáról, illetve nyilatkoztatni kellett őket az IBR-ben való részvételi akaratukról. Az ellátásszervezók azonban ennek a kötelezettségüknek nem tettek eleget, így a megtakarítási kifizetések nem történtek meg. „A kifizetések teljesítésének feltétele volt, hogy a 331/2005. (XII.29) Kormányrendelet 18. §-a alapján az IBR átfogó éves ellenőrzó vizsgálata megtörténjen. Ennek során megállapításra került, hogy 2006. évben a szervezôk nem tettek eleget törvényi kötelezettségüknek, mivel az egészségügyi és személyes adatok kezeléséról és védelméról szóló 1997. évi XLVII. törvény 22/B §-ban foglaltak szerint nem történt meg a biztosítottak értesítése és emiatt - adatszolgáltatás hiányában - az IBR lényegét képező betegút-követő tevékenység nem volt ellátható." (Pénzügyminisztériumi Zárszámadás 2008: 4)

A kifizetések elmaradása miatt, a szervezôk korábbi megtakarításaikat használták fel 2007-es múködésük során. 2008-ban az OEP egyetlen szervezôvel sem kötött szerzôdést, így az IBR gyakorlatban nem, elviekben még múködött ebben az 
évben. A szervezőnél megmaradt, korábban utalványozott összegeket a szervezônek az OEP felé vissza kellett fizetni, az IBR pedig a 348/2008. (XII. 31.) Kormány Rendelet értelmében 2009. január 1-el megszúnt létezni.

\section{Összegzés}

Az IBR alkalmazása 2006-tól kezdve egyre inkább háttérbe szorult, bár megszüntetése hivatalosan nem hangzott el, mégis leépítették 2008. márciusára. Megszûnésének valódi okairól a mai napig keveset tudunk. Az OEP még az indulásnál rendkívül elismerôen nyilatkozott az irányított betegellátási modellrôl, míg az ÁSZ mélyen elítélte. Az IBR civil kezdeményezésként jött létre, olyan csoportosulás érdekérvényesítése nyomán formálódott, amely hitt a piaci megoldásokban, a versenyen alapuló reformokban. Ez a szemlélet nem egyezett meg sem az OEP, sem az Egészségügyi Minisztérium koncepcióival, így a szakma nagyobb része, valamint az egészségügyi rendszer adott rétege kellő távolságból szemlélte az IBR múködését. Nem helyezték hatályba azokat a jogszabályokat, amelyek nélkülözhetetlenek lettek volna az IBR stratégiai fenntartásához. Az Egészségügyi Minisztérium elvi-politikai okokból elhatárolódott az ilyen típusú reformoktól, amit azzal magyarázott, hogy az IBR szabályozatlan, dilemmákkal és feszültséggel terhes az új rendszer. A kormányzat a továbbiakban nem tudott felelősséget vállalni az IBR-ért, ezért kihátrált mögüle.

\section{Irodalomjegyzék}

1. Barr, Nicholas (2009): A jóléti állam gazdaságtana. Budapest: Akadémiai Kiadó.

2. Belicza Éva - Boncz Imre - Horváth Ágnes - Jónásné Katona Katalin (szerk.): Irányított betegellátási rendszer múködésének értékelése 1999-2003. Budapest: Országos Egészségbiztosítási Pénztár. 2004.

3. Birenbaum, Arnold (1997): Managed Care: Made in America. Westport: Praeger.

4. Boncz Imre - Dózsa Csaba - Gulácsi László (szerk.): Forrásallokációs mechanizmusok és irányított betegellátás. Budapest: OEP. 2004.

5. Boncz Imre - Dózsa Csaba (2003): Irányított betegellátási modell (IBM): a fejkvótaszámítás szerepe és módszertana. Informatika és Menedzsment az Egészségügyben, 6: 19-22.

6. Boncz Imre - Horváth Ágnes - Jónásné Katona Katalin - Dózsa Csaba (2004): Az irányított betegellátási rendszer fejlődése és múködése. Lege Artis Medicinae, 6: $448-449$.

7. Boncz Imre - Horváth Boldizsár (szerk.): Az egészségügyi gazdaságtan alapfogalmai. Pécs: PTE EFK. 2001.

8. Boncz Imre (2004): A magyar Irányított Betegellátási Rendszer (IBR) tapasz- 
talatai. Kórház, 9: 29-30.

9. Bordás István (2005): Az ellátásszervezésről (irányított betegellátásról). Egészségügyi Gazdasági Szemle, 1: 36-44.

10. Boromisza Piroska (2004): Fókuszban az Irányított Betegellátási Rendszer. Informatika és Menedzsment az Egészségügyben. 5: 5-7.

11. Csedô Zoltán - Nagy Balázs - Dobák Miklós - Dózsa Csaba - Gulácsi László (2003): Új modellek a modellben: felsôvezetôi kihívások az irányított betegellátási modell tükrében. Orvosi Hetilap, 23: 1135-1143.

12. Dixon, Michael - Sweeney, Kieran (szerk.): A Practical Guide to Primary Care Groups and Trusts. Oxon: Radcliffe Publishing. 2001.

13. Donkáné Verebes Éva - Dózsa Csaba (1999): Az irányított betegellátás modellkísérlet kezdeti tapasztalatai és a továbblépés lehetôség. Egészségügyi Menedzsment, 1: 41-45.

14. Gabe, Jonathan - Calnan, Michael - Bury, Michael (szerk.): Follow up to: The Sociology of the Health Service. London: Routledge. 2009.

15. Gilly Gyula - Szabó Alexandra (2004a): A magyar irányított betegellátási modell. I. rész. Kórház, 2: 14-21.

16. Gilly Gyula - Szabó Alexandra (2004b): A magyar irányított betegellátási modell. II. rész. Kórház, 3: 14-18.

17. Gulácsi László - Kovács Erzsébet - Oesterle, August - Boncz Imre (2007): Verseny az egészségügyben. Egyesült államokbeli és nyugat-európai példák. Közgazdasági Szemle, 5: 480-498.

18. Gulácsi László (szerk.): Egészség-gazdaságtan. Budapest: Medicina Könyvkiadó. 2005.

19. Harris, Marilyn D. (szerk.): Handbook of Home Health Care Administration. Massachusetts: Jones and Bartlett Publishers. 2005.

20. Karner Cecília (2008): Nemzetközi egészségügyi finanszírozási modellek és az állam szerepvállalása. Egészségügyi Gazdasági Szemle, 2: 3-12.

21. Kerekes László (2003): A szakmai protokollok jelentôsége az Irányított Betegellátási Modellben. Informatika és Menedzsment az Egészségügyben, 7: 13-16.

22. Kincses Gyula (2006): Az egészségügyi rendszer jellegzetességei. In.: Szántó Zsuzsa - Susánszky Éva (szerk.): Orvosi szociológia. Budapest: Semmelweis Kiadó. $160-176$.

23. Kincses Gyula (2007): Az USA managed care rendszereinek magyarországi adaptálhatósága. Budapest: Egészségügyi Stratégiai Kutatóintézet.

24. Kongstvedt, Peter Reid (2007): Essentials of Managed Health Care. Massachusetts: Jones \& Bartlett Publishers.

25. Kongstvedt, Peter Reid (2008): Managed Care: What It Is and How It Works. Massachusetts: Jones \& Bartlett Publishers 
26. Kongstvedt, Peter Reid (szerk.): The Managed Health Care Handbook. Massachusetts: Jones and Bartlett Publishers. 2001.

27. Kornai János (1998): Az egészségügy reformjáról. Budapest: Közgazdasági és Jogi Kiadó.

28. Kornai János (2004): Egyéni választás és szolidaritás. Az egészségügy intézményi mechanizmusának reformja Kelet-Európában. Budapest: Nemzeti Tankönyvkiadó.

29. Kornai János (2008): A puha költségvetési korlát szindrómája a kórházi szektorban. Közgazdasági Szemle, 12: 1037-1056.

30. Közlekedési, Hírközlési és Energiaügyi Minisztérium Zárszámadása, 2002.

31. Marton Imelda (2004): Az irányított betegellátás rendszerbe állítása - társadalombiztosítás vagy üzleti biztosítás. Egészségügyi Gazdasági Szemle, 5: 30-41. 32. Matejka Zsuzsa (2001): Az irányított betegellátás a szervezők szemével. Egészségügyi Gazdasági Szemle, 4: 355-362.

33. Matejka Zsuzsa (2002): A prevenció költséghatékonysága. Egészségügyi Menedzsment, 2: 92-93.

34. Matejka Zsuzsa (2004): Az Irányított Betegellátási Rendszer 2004. évi változásai. Budapest, OEP.

35. Mihályi Péter (2003): Bevezetés az egészségügy közgazdaságtanába. Veszprém: Veszprémi Egyetemi Kiadó.

36. Mihályi Péter (2005): Az irányított betegellátás védelmében. Informatika és Menedzsment az Egészségügyben, 8: 12-13.

37. Mikola István (1998): A "köz" és a "magán" viszony az egészségügyi ellátórendszerben. In.: Glatz Ferenc (szerk.): Egészségügy és piacgazdaság. Budapest: Magyar Tudományos Akadémia. 13-23.

38. Moseley, George B. (2008): Managing Health Care Business Strategy. Massachusetts: Jones and Bartlett Publishers.

39. Nagy Balázs - Dózsa Csaba - Boncz Imre (2004): A fejkvótaszámítás továbbfejlesztésének lehetôségei az irányított betegellátásban. Egészségügyi Gazdasági Szemle, 1: 15-25.

40. Nagy Balázs - Dózsa Csaba (2002): Az irányított betegellátási modellkísérlet tapasztalatai. Egészségügyi Menedzsment, 1: 55-60.

41. Orosz Éva (2001): Félúton vagy tévúton? Budapest: Egészséges Magyarországért Egyesület.

42. Pénzügyminisztériumi Zárszámadás, 2001.

43. Pénzügyminisztériumi Zárszámadás, 2003.

44. Pénzügyminisztériumi Zárszámadás, 2004.

45. Pénzügyminisztériumi Zárszámadás, 2005.

46. Pénzügyminisztériumi Zárszámadás, 2006.

47. Pénzügyminisztériumi Zárszámadás, 2007.

48. Pénzügyminisztériumi Zárszámadás, 2008.

49. Rácz Jenô (2003): Az Irányított Betegellátási Modell a helyi lakosság szükségleteit tartja szem elótt. Egészségügyi Menedzsment, 1: 78-79. 
50. Simon Kis Gábor (2003): Az amerikai Managed Care és a magyar irányított betegellátás. Egészségügyi Menedzsment, 1: 76-77.

51. Sinkó Eszter (2002): Az irányított betegellátás és a hazai egészségügy kapcsolata. Egészségügyi Gazdasági Szemle, 6: 673-680.

52. Stiglitz, Joseph E. (2000): A kormányzati szektor gazdaságtana. Budapest: Közgazdasági és Jogi Kiadó.

53. Todd, Maria K. (2009): The Managed Care Contracting Handbook. New York: CRC Press.

Jóna György fóiskolai adjunktus

Debreceni Egyetem, Egészségügyi Kar, Nyíregyháza, 4400, Sóstói út 2-4.

Kriszbacher Ildikó egyetemi docens

Pécsi Tudományegyetem, Egészségtudományi Kar, 7621 Pécs, Vörösmarty u. 4.

Lukácskó Zsolt főiskolai tanár

Debreceni Egyetem, Egészségügyi Kar, Nyíregyháza, 4400, Sóstói út 2-4. 